\title{
Komodifikasi Ruang dalam Program Televisi di Indonesia
}

\section{Commodification of Space in Television Programs in Indonesia}

\author{
Rino Andreas ${ }^{\text {a, }}$ * \\ ${ }^{a}$ Kajian Budaya dan Media, Universitas Gadjah Mada, Indonesia \\ ${ }^{1}$ rinoandreas19@gmail.com \\ *korespondensi penulis
}

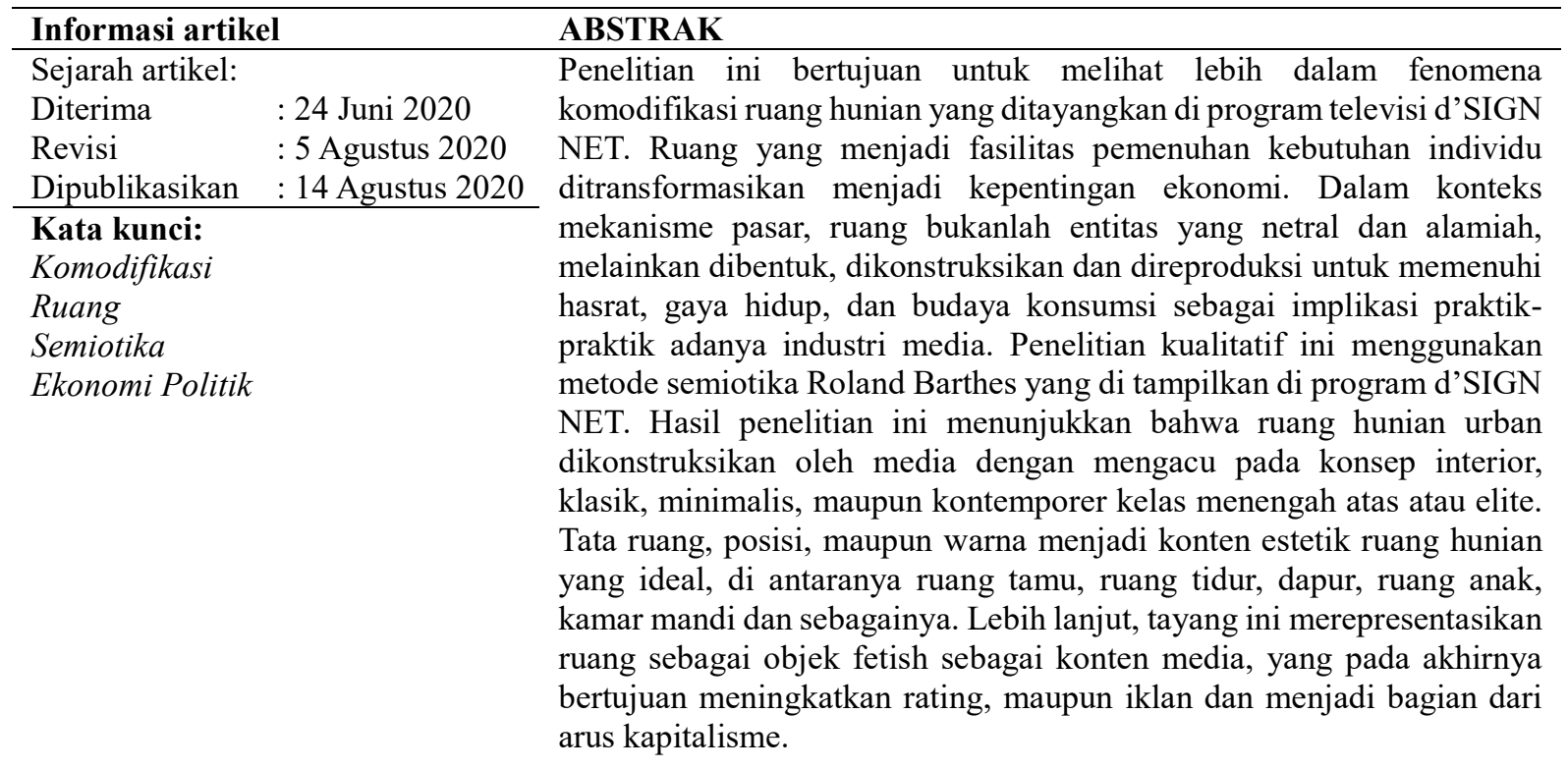

Keywords:
Commodification
Space
Semiotic
Political Economy

ABSTRACT

Commodification of Space in Television Programs in Indonesia This paper aims to see the phenomenon of commodification of housing space on television program, called d-SIGN NET. Spaces which are facilities to meet individual are transformed into economic interests. In the context of market mechanisms, space is not a neutral and natural entity, but is formed, built and reproduced to meet the desires, lifestyles and consumption culture as an implication of the practice of the media industry. This qualitative research uses the Roland Barthes semiotic method which is featured in the d'SIGN NET program. The results of this study indicate that urban residential spaces are built by the media by referring to the interior, classical, minimalist, and contemporary concepts of the upper middle class. The layout, the position, and the color become the aesthetic content of the ideal residential space, including the living room, bedroom, kitchen, children's room, bathroom and so on. Furthermore, this program represents space as an object of fetish as media content, which ultimately aims to improve rankings, as well as advertisements and become part of capitalism system. 


\section{Pendahuluan}

Ruang, menjadi topik yang menarik untuk ditelisik seiring dengan perkembangan industrialisasi saat ini. Kajian mengenai ruang (space) mendapatkan perhatian para ilmuan, karena mengalami perubahan dari waktu ke waktu. Kondisi ini dipengaruhi semakin berkembangnya teknologi dan terpaan media yang mengamokodasi kebutuhankebutuhan masyarakat secara luas. Ruang seringkali dipertentangkan dengan konsep 'tempat'. Pada tahun 1970-an dan 1980-an konsep 'tempat' cenderung dipahami sebagai konsep geografi historis dan empiris, kemudian karya berpengaruh David Harvey, terutama The Limits to Capital (1982) dan The Urbanization of Capital (1985) adalah konsep pemikiran yang ditawarkan dari 'tempat' menuju konsep 'ruang'. Dalam karya-karya ini, Harvey memanfaatkan analisis Marxis yang melihat ruang sebagai produksi komoditas; dengan demikian, konflik kelas tampak jelas di dalamnya. Melalui pendekatan yang lebih teoretis ini, para ilmuan sosial humaniora secara bertahap menggantikan gagasan lama tentang konsep 'tempat' yang merujuk pada kondisi geografis yang statis menjadi 'ruang' yang dipahami secara dinamis, dikonstruksi, dan diperebutkan. Di dalamnya ruang menampilkan berbagai isu sentral kehidupan manusia terkait seksualitas, ras, kelas, dan gender di antara segudang perjuangan kekuasaan dan pengetahuan lainnya yang diletakkan, diciptakan, termasuk ruang hunian urban yang dapat diamati dalam program televisi NetTV yaitu d'SIGN

d'SIGN merupakan program magazine yang mengulas tentang karya dunia desain ruang, baik karya arsitektur yang unik dan menarik, ide desain interior, desain furniture, hingga berbagai gaya seni yang menjadi referensi gaya desain ruang hunian. D'SIGN juga berisi tayangan dengan berbagai tips dekorasi aplikatif yang ditayangkan setiap sabtu dan minggu pukul 16.00 WIB di NET TV. NET (News and
Entertainment Television) adalah sebuah stasiun televisi swasta terestrial nasional di Indonesia yang dimiliki oleh Net Visi Media yang yang sebagian sahamnya telah dimiliki oleh PT Net Mediatama Televisi. Media yang memiliki slogan "NET. Asiknya 24 Jam" ini telah menjangkau hingga 43 stasiun transmisi melalui 156 kota di Indonesia. Program serupa juga dapat diamati di stasiun televisi Trans7 yaitu Rumah Impian, maupun The Project di Trans TV.

Program d'SIGN menjadi tayangan yang menampilkan representasi ruang hunian urban, melalui media. Dalam perspektif ekonomi politik konten tersebut merupakan tayangan yang di produksi oleh kelas pemilik modal. Tinjauan kritis mengenai ruang dipopulerkan oleh pemikir neo-marxist Henri Lefebvre.

Media sebagai instrumen komunikasi pada gilirannya melihat konsep ruang yang dikemas dalam sebuah program televisi, dimana ruang hunian urban dikomodifikasikan sebagai bagian dari kebutuhan selera pasar. Perusahaan memanfaatkan media dalam penyampaian konten-konten tersebut kepada publik, baik melalui media konvensional maupun media baru. sehingga dapat meningkatkan popularitas dan mempertahankan eksistensi dalam persaingan antar media.

Penelitian sebelumnya mengenai komodifikasi di media massa memang beragam misalnya komodifikasi privasi (Christy, 2018), komodifikasi nasionalisme (Syafuddin \& Andreas, 2018), komodifikasi kemiskinan (Arya,2016) komodikiasi perempuan (Swastika, 2003), maupun komodifikasi agama (Yusriyah, 2016). Begitupun dengan ruang yang politis, dielaborasi oleh Kamil Alfi Arifin (2017) yang menganalisis secara jelas bagaimana produksi ruang yang berlangsung dalam pembangunan perumahan Muslim dan hubungan ekonomi-politik yang dapat dijumpai melalui kepentingan antara pihak developer dan elit kelompok-kelompok 
Islam yang terlibat dalam proses produksi spasial untuk perumahan Muslim tersebut.

Berdasarkan uraian pengantar diatas, maka peneliti akan mengelaborasi pertanyaan "bagaimana proses komodifikasi terhadap ruang hunian urban dalam program d'SIGN? Sejauh mana ruang dikonstruksikan melalui tanda-tanda visual dalam program tersebut? Penggambaran yang divisualisasikan kemudian membuat ruang hunian yang diidealkan menjadi sebuah komoditas yang dapat digunakan untuk kepentingan perusahaan. Pada bab selanjutnya akan dibahas mengenai konseptualisasi antara komodifikasi sebagai analisis ekonomi politik dan konsep mengenai ruang secara reflektif dan kritis.

\section{Metode}

Penelitian kualitatif ini menggunakan metode Semiotika Roland Barthes, dengan kajian ekonomi politik oleh Vincent Mosco. Semiotika tidak hanya sebatas bahasa, namun segala hal di luar bahasa. Pendekatan Roland Barthes digunakan untuk menjelaskan aspek mitos berdasarkan tanda yang muncul (Budiman, 2011). Penelitian ini didasarkan pada analisis secara reflektif dan kritis berdasarkan pada data primer dan data sekunder. Data primer terdiri dari scene-scene dalam program televisi d'SIGN yang tayang di Net TV. Sedangkan data sekunder terdiri dari literatur yang relevan dari jurnal, buku dan penelitian terdahulu.

Secara metodologis, Roland Barthes menekankan pendekatan multi disiplin terhadap budaya konsumen, yakni menggunakan linguistik, psikoanalisis, sejarah, dan politik, sehingga sangat relevan diterapkan dalam studi mengenai desain ruang. Dalam mengembangkan konsep kritisnya, Barthes menggunakan analisis serangkaian praktik mitologis, sebagai proses yang kreatif dan responsif terhadap perkembangan masyarakat yang dinamis. Barthes memperkenalkan konsep "Myth Today" hadirnya mitos dapat muncul, berubah, hancur, maupun menghilang
(Barthes 1973: 130). Bertentangan dengan konsep modernis yang memiliki sifat universal dan tetap yang berorientasi pada "desain yang baik,". Analisis Barthes yang cair dan kritis, dapat beradaptasi dalam pergeseran dinamika sosial dan kerangka kerja politik. Barthes memanfaatkan konsep dan terminologi dari bidang linguistik Ferdinand de Saussure, dimana Barthes mengambil gagasan mitos sebagai suatu sistem komunikasi atau mode of significance (Barthes 1973: 117). Sebaliknya, ia tidak melihat artefak budaya sebagai entitas yang otonom, namun melihatnya secara struktural dan relasionalyang saling terikat.

Menurut Barthes, tanda terkait dengan faktor estetika dan ideologis yang memungkinkan dibaca secara terbuka. Interpretasi pada tingkat konotatif dilakukan untuk menjelaskan bagaimana makna diciptakan oleh hubungan tandatanda yang kompleks. Dengan demikian, semiotika dalam studi media menggunakan berbagai macam teks sehingga dapat dipahami oleh pembacanya. Dari perspektif ini, muncul istilah the death of authors/ pencipta teks, yakni penerima yang memungkinkan untuk menafsirkan, membaca, dan menghasilkan berbagai makna yang merupakan bentuk produksi semiotik yang berorientasi pada pengamatan analisis pesan dalam konteks media.

'Lebih jauh, semiologi sebagai metode kualitatif yang diterapkan dalam riset media membantu peneliti memahami relasi tanda dalam konteks sosial-budaya, yang dimanifestasikan baik dalam bentuk verbal maupun nonverbal (Bouzida, 2014). Tanda yang diamati meliputi kombinasi dari signifier dan signified yakni dalam level denotatif dan konotatif. Untuk memperjelas dapat dilihat berdasarkan tabel berikut: 


\begin{tabular}{|c|c|}
\hline $\begin{array}{c}\text { 1.Signifier } \\
\text { (penanda) }\end{array}$ & $\begin{array}{c}\text { 2.Signified } \\
\text { (petanda) }\end{array}$ \\
\cline { 1 - 1 } $\begin{array}{c}\text { 3.Denotative sign } \\
\text { (tanda denotatif) (first system) }\end{array}$ \\
\hline $\begin{array}{c}\text { 4.Connotative Signifier } \\
\text { (penanda konotasi) }\end{array}$ & $\begin{array}{c}\text { 5. Connotative Signified } \\
\text { (petanda konotasi) }\end{array}$ \\
\hline \multicolumn{2}{|c|}{ 6.Connotative Sign (tanda konotasi) (second system) } \\
\hline
\end{tabular}

Tabel 1. Model semiotika Roland Barthes

\section{Komodifikasi}

Pendekatan Ekonomi Politik media memiliki variasi tersendiri, diantaranya, pemikiran yang ditawarkan oleh Robert Mc Chesney (1997), Golding dan Murdock (1986), Politik propaganda media Herman dan Noam Chomsky (1988) maupun Ekonomi politik komunikasi di abad 21 oleh Janet Wasko (2014). Sedangkan dalam kajian ekonomi politik media yang dikemukakan oleh Vincent Mosco dibagi kedalam tiga hal, di antaranya komodifikasi, spasialisasi, dan strukturasi. Komodifikasi merupakan bentuk komoditi dalam komunikasi yang memanfaatkan isi pesan dalam proses yang berlangsung di industri media guna menciptakan pesan dari data yang terkumpul menjadi produk yang dapat dijual (Mosco dalam Hareyah, 2012). Lebih lanjut, Komodifikasi dapat dipahami sebagai proses transformasi barang atau jasa yang nilai guna (nilai yang didasarkan pada kemampuan memenuhi kebutuhan) menjadi nilai tukar (nilai yang berorientasi pada pasar). Komodifikasi menjadi salah satu cara dalam pendekatan media massa dalam pendekatan ekonomi politik. Vincent Mosco (2009:132), mendefinisikan komodifikasi sebagai proses mengubah nilai pada suatu produk yang tadinya hanya memiliki nilai guna kemudian menjadi nilai jual. Dalam konsep komodifikasi ini, Mosco (2009) menyebutkan bahwa komunikasi merupakan arena potensial tempat terjadinya komodifikasi. Hal ini dikarenakan komunikasi merupakan komoditas yang sangat besar pengaruhnya karena yang terjadi bukan hanya komodifikasi untuk mendapatkan surplus value, tapi juga karena pesan yang disampaikan mengandung simbol dan ideologi yang bisa dimanfaatkan untuk mempertajam kesadaran penerima pesan. Dengan demikian, ringkasnya komodifikasi mengacu pada proses transformasi produk/komoditas yang memenuhi kebutuhan individu dan sosial menjadi produk yang nilainya ditentukan oleh mekanisme pasar. Sedangkan Murdock mendefinisikan komoditas sebagai barang atau jasa yang dijual dengan harga di pasar untuk mendapatkan keuntungan (Myllylahti, 2017).

\section{Representasi Ruang, Praktik Ruang dan Ruang Representasi}

Pada tahun 1974 Lefebvre menerbitkan bukunya In La Production de l'Espace (1974), Buku ini merupakan karya reflektif yang membahas aspek politis, sosiologis dan filosofis pada hubungan antara pedesaan, perkotaan, industrialisasi, komodifikasi, perkotaan perencanaan, negara dan teknokrasi (Mendieta, 2008). Lefebvre mengeksplorasi hubungan dua ' dimensi ' ruang dan waktu sebagai ' momen ' tertentu dalam rangka untuk menghasilkan pemeriksaan kritis terhadap kehidupan sehari-hari atau bagaimana terjadinya perubahan sosial dan budaya pada tingkat individu (Beebe, 2012). Lefebvre mengakui ruang sebagai sebuah lokasi serta fenomena metaforis dan sosial. Menurut Lefebvre, sosial ruang adalah produk sosial (Lefebvre, 1991:27). Untuk memahami dasar ini, perlu untuk beralih dari pemahaman bahwa ruang yang dibayangkan bukan sebagai realitas material independen yang ada 'dalam dirinya sendiri' atau alamiah. Lefebvre berpendapat bahwa ruang tidak ada dalam dirinya sendiri, namun diproduksi secara sosial (Schmid, 2008). Untuk mengelaborasi lebih jauh konsep produksi ruang, Lefebvre membangun triad spasial. Konsep yang menjelaskan bagaimana ruang yang diproduksi, dihubungkan dengan ruang fisik, ruang mental dan ruang sosial 
sementara pada saat yang sama mengimplikasikan pentingnya kehidupan sehari-hari. Fondasi epistemologi dari teori Lefebvre adalah posisinya tentang triad spasial, yang menggunakan tiga pertimbangan ruang, untuk membuat kejelasan kompleksitas kehidupan seharihari. Ia menyarankan bahwa ruang adalah dasar dari pengalaman hidup dan setiap pengalaman terdiri dari tiga aspek ruang yang saling terkait antara lain: representations of space (conceived space), spatial practices (perceived space), dan spaces of representation (lived space).

Pertama, representasi ruang, praktik spasial (ruang dirasakan), dan ruang representasi (ruang hidup). Representasi ruang, Lefebvre (1991: 38-9) mengemukakan adalah ruang yang dominan di masyarakat dan merupakan ruang konseptual yang dibangun dari simbol, kodifikasi dan abstrak representasi. Kedua, praktik spasial mencakup 'produksi dan reproduksi, dan khususnya lokasi dan tata ruang menentukan karakteristik setiap formasi sosial (Lefebvre, 1991: 33) dan sebagai seperti itu datang bersama dengan dua elemen triad lainnya untuk memastikan tingkat kohesi dan kompetensi yang dibutuhkan untuk fungsi sehari-hari masyarakat, peristiwa spasial kehidupan. Ketiga, yang melengkapi model triadik, sebagai ruang representasi, ruang pengalaman hidup; ini adalah ruang 'yang langsung dijumpai melalui gambar terkait dan simbol, "inhabitants" dan "users", (Lefebvre, 1991: 39) Lefebvre menegaskan bahwa hal itu adalah interaksi dari tiga dimensi yang membentuk ruang sosial dan menegaskan bahwasanya ruang bukanlah entitas yang saling terpisah (Lefebvre, 1991:40-43)

Hendry Lefebvre secara luas diakui hari ini sebagai salah satu sosiolog, filsuf, dan ahli geografi terkemuka dunia dari periode pasca-Perang Dunia Kedua. Di Perancis, reputasinya sebagai salah satu kontributor dalam epistemologi Marxist menempatkannya di sebelah tokoh-tokoh seperti Jean-Paul Sartre dan Louis
Althusser. Lefebvre adalah pemikir abad kedua puluh, yang karyanya berhasil mengintegrasikan kritik kapitalisme di kehidupan sehari-hari 'everyday life' dan 'produksi ruang' (Foster, 2020).

\section{Hasil dan pembahasan \\ Komodifikasi Ruang dalam Media}

Program televisi d'SIGN telah memiliki banyak episode dan tayang setiap minggunya. Tayangan yang menampilkan ruang hunian idaman ini dipersiapkan mulai dari materi, lokasi yang ditentukan, perijinan, transportasi dan proses pengambilan gambar oleh tim produksi NET. Pada salah satu episode yang yang berjudul "Home Sweet Home ala Gisella Anastasia" d'SIGN secara spesial berkunjung di rumah salah satu aktris terkenal di Indonesia yaitu Gisella Anastasia. Visualisasi ruang yang lekat dengan masyarakat urban ini diawali dengan tampilan depan rumah Gisella yang berada di kawasan elite Pesanggrahan di Jakarta Selatan. Di depan rumah berlantai dua tersebut terdapat mobil mewah yang terparkir sebagai scene pembuka. Pemilik rumah dalam hal ini Gisella, menyapa audiens yang akan mengeksplorasi bagian dalam rumahnya seperti terlihat dalam Gambar.1. Sebelumnya dapat dipahami bahwa konsep ruang yang diidamkan Gisella dibangun berdasarkan "ruang mental" atau representations of space yang dibangun berdasarkan pengalaman sosiokulturalnya, yang kemudian diwujudkan menjadi ruang "nyata". Ruang dominan dalam masyarakat saat ini merupakan ruang yang dikonseptualisasikan dan dibangun dari simbol, kodifikasi dan representasi abstrak. Representasi media itu adalah bangunan logika dan bentuk pengetahuan, dan konten ideologis kode, teori, dan penggambaran konseptual ruang (Shields, 1999: 163). Dengan demikian ruang merupakan representasi nyata dari konstruksi mental tentang ruang-ruang dari pemahaman rasional dan abstrak. Aspek inilah yang mengkodifikasikan pendekatan 
epistemologi untuk memahami, menentang klaim pengetahuan dan kebenaran tradisional tentang ruang yang tetap dan netral. Representasi muncul melalui proliferasi sistem simbol yang menyediakan kategori, bentuk dan taksonomi, yang mendominasi upaya pemahaman dan representasi ruang hunian dalam masyarakat modern.

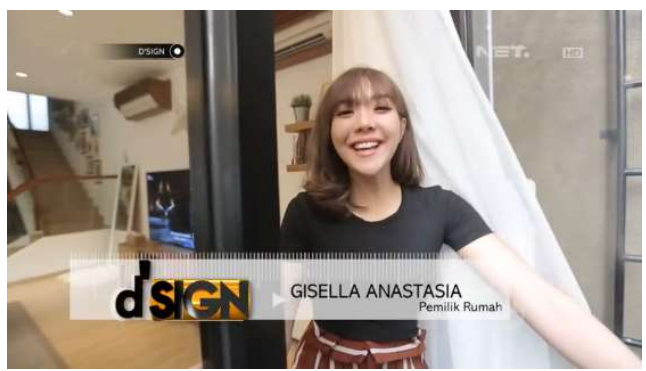

Gambar 1. Gisella sedang menyapa audiens

Menariknya

untuk mentransformasikan konsep ruang yang diidealkan itu pemilik rumah bekerja sama dengan Tim Design Interior RSI grup. Hal itu dimaksudkan untuk mewujudkan aspek mental ruang ke dalam kode, simbol yang dapat diamati, dan di rasakan secara empiris yakni tema American Classic yang memilki karakteristik detail dengan kesan feminin, maupun tema Skandinavian yang mempunyai ciri kasual dan ikonik. Analisis awal dapat diasumsikan bahwa media memiliki afilisasi dengan RSI Grup yang dikenal sebagai adalah tim desain dengan standar internasional dalam pembangunan hotel, apartemen, perumahan pribadi, restoran, ritel dan gedung pencakar langit.

Program tayangan

d'SIGN menampilkan visualisasi landscape ruang hunian urban ala Gisella yang hibrid, dan dinamis. Tampilan yang dekat dengan kelas menegah atas bahkan kelas elite, seperti artis yang memiliki kapital ekonomi dan simbolik yang kuat. Penggambaran ruang hunian artis yang populer menjadi bentuk legitimasi bagaimana ruang dibentuk, dan dikonstruksikan oleh masyarakat perkotaan di era kontemporer, berbeda dengan ruang hunian masyarakat rural. Jadi seolah-olah audiens diarahkan untuk memiliki semacam blue print ruang impiannya tersendiri berdasarkan tayangan d'SIGN. Yakni semua yang dibutuhkan, maupun petujuk ada dalam teks. Pada akhirnya masingmasing individu ingin membedakan diri dengan orang lain (distingsi) untuk mengatur ruang hunian secara bebas yang terasa menyenangkan.

Lebih lanjut, ruang kemudian dipahami dengan kategorisasi yang dipisah berdasarkan fungsi, dan subjek yang menempati ruang tersebut sebagaimana dapat diamati, rumah hunian Gisella yang di tayangkan d'SIGN di bagi kedalam beberapa ruang, diantaranya, ruang tamu, ruang dapur, ruang anak, kamar mandi, kolam renang dan lain sebagainya. Setiap ruang difungsikan dengan tujuan yang berbeda-beda. Sebagaimana kriteria rumah yang sebetulnya satu bagian yang utuh, namun dipahami dengan cara yang terpisah dan dapat dimodifikasi.

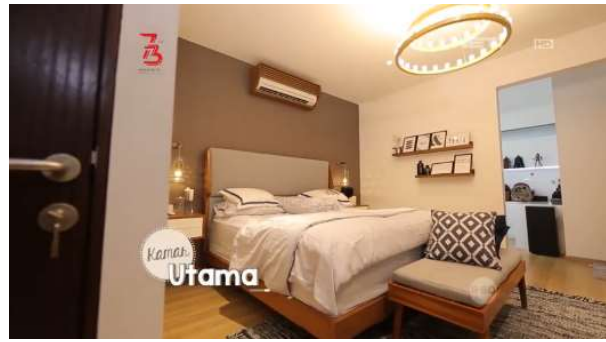

Gambar 2. Ruang utama hunian

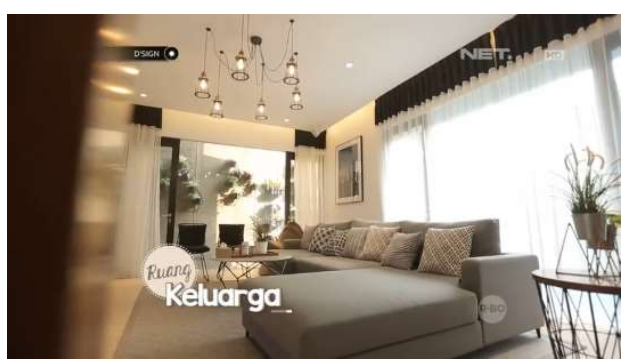

Gambar 3. Ruang Keluarga

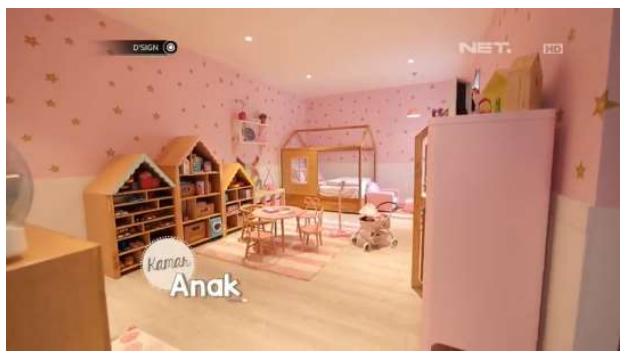

Gambar 4. Ruang Anak 


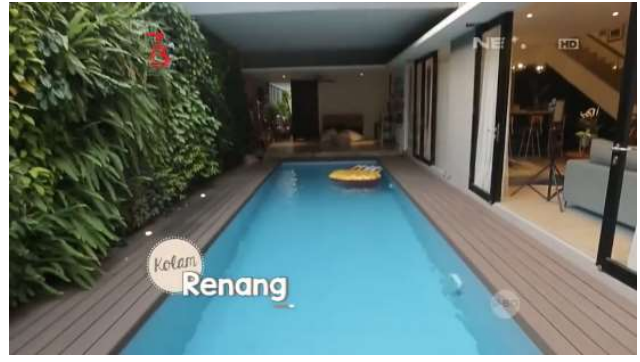

Gambar 5. Kolam renang

Dapat diamati ruang utama dapat difungsikan untuk tidur kedua orang tua. Sedangkan ruang anak dipisahkan tersendiri sebagai arena bermain dan belajarnya. Begitu pula ruang keluarga dan kolam renang yang dapat dipahami sebagai ruang berkumpul dan berinteraksi secara sosial, di ruang privat. Proses produksi dan reproduksi lokasi-lokasi serta tata ruang memiliki ciri khasnya tersendiri, tentu bukan sebagai sesuatu yang alamiah dan taken for granted melainkan terdapat aspek peniruan dari pengalaman sosio-kultural sebelumnya. Hubungan antara individuindividu dan ruang memungkinkan partisipasi untuk membentuk, mengatur ulang secara spasial yang meliputi rutinitas sehari-hari berdasarkan konvensi perilaku sosial. Sebagaimana elemen ketiga dari triad, ruang representasi adalah ruang pengalaman hidup, ruang itu "hidup" melalui gambar dan simbol yang saling terkait (Lefebvre, 1991: 39). Ruang representasi itu merupakan ruang fisik, konkrit dan aktual seperti yang hidup dalam kehidupan sehari-hari. Ini adalah aspek ruang yang mencakup keberpihakan representasi dan sistem pengetahuan. membentuk, menginformasikan dan memfasilitasi aspek dasar individualitas dari setiap pertemuan sosial. Kehadiran elemen triadik ini jelas ditunjukkan oleh kesadaran para individu terhadap peran yang dimainkan oleh ruang fisik aktual.

Praktik spasial terhadap kondisi persepsi orang realitas sehari-hari berhubungan dengan penggunaan ruang, rute, jaringan dan pola interaksi yang menghubungkan tempat-tempat yang disisihkan untuk bekerja, bermain, dan bersantai (Merrifield, 1993).

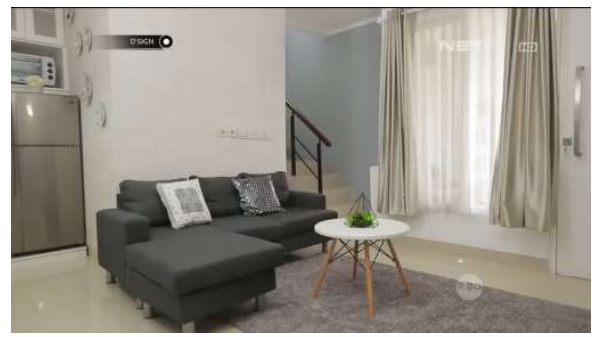

Gambar 6. Furnitur ruang tamu

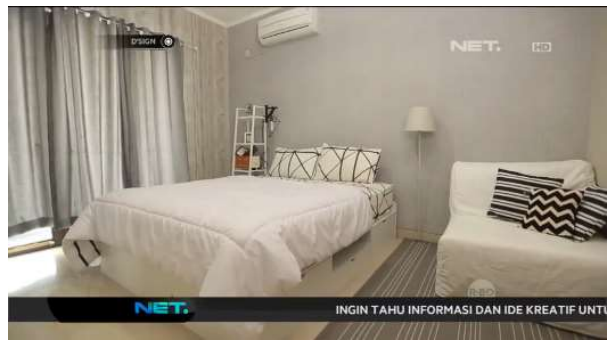

Gambar 7. Interior kamar

Di tayangan yang berbeda, program d'SIGN juga menampilkan konsep ruang bertemakan Skandinavia. Setiap ruang diisi berbagai perabotan yang dianggap cocok dan proporsional dengan bentuk dan warnanya. Setiap furniture terdiri dari bahan dan material yang berbeda. Disesuaikan dengan kebutuhan ruang untuk membangun representasi ruang dengan kesan tertentu yang mengarah pada ruang representasi. Misalnya bentuk kursi, bentuk meja, karpet dan lain sebagainya. Penataan itu tentu saja berdasarkan kredo gerakan arsitektur modern yang terkenal yakni "form (ever) follows function".

\section{fetishism \\ Ruang sebagai objek commodity}

kritik Lefevbre terhadap kapitalisme itu sendiri, terutama kritik terhadap representasi ruang di bawah kapitalisme. Hal itu terlihat ketika media banyak mengeksplorasi obyek bangunan sesuai dengan pola-pola khas dalam arsitektur model Barat seperti gaya Amerika atau Eropa, baik dari sisi "wajah" bangunan, seperti facade, atau dari sisi "kulit" bangunan, seperti struktur dan ornamen- 
ornamen dan lain sebagainya. Penataan interior perumahan juga dikonstruksikan sesuai dengan standarisasi estetika ruang hasil dari aspek mental pemilik rumah dan tim desain interior. Bentuk furniture yang menjadi bagan dari representasi ruang kemudian meninggalkan nilai kegunaannya dan bertransformasi sebagai bentuk lifestyle yang pada akhirnya menciptakan ideologization of commodities dan commoditization of ideologies. Dua konsep yang mengacu pada proses-proses yang menyambungkan dan melekatkan (embodiment) nilai-nilai, ide-ide dan ideologi pada suatu komoditas yang dipahami memilki aspek modern, futuristik, eksklusif dan elegan. Mengingat bahwa media memiliki kepentingan akumulasi kapital, dirumuskan beberapa ilmuwan sosial kritis, ruang selalu diyakini sebagai hasil dari konstruksi sosial, dari relasi-relasi sosial yang dinamis dan terus berubah dan selalu bertautan dengan relasi kekuasaan dan simbolisme (Arifin, 2017) Hal itu sejalan dengan prospek pasar yang potensial. Mengingat jumlah kelas menengah di Indonesia cukup besar.

Hegemoni kekuasaan media memainkan visualisasi ruang yang terikat dan tak bisa dilepaskan dari realitas sosial politik-ekonomi yang melingkupi gelombang kapitalisasi. Mengikuti Marx (1906), suatu produk menjadi komoditas ketika produksinya diatur melalui proses pertukaran (Mosco, 1996:141), dan nilai tukar menjadi dapat dibedakan melalui penempatan produk di pasar tempat komoditas diambil. Dengan kata lain, komoditas menjadi fetis (Tracy, 2004). Pemujaan terhadap ruang dan objek terlihat ketika pemilik hunian rela untuk melakukan import dan mengoleksi berbagai furnitur yang langka dan mahal. Implikasi lebih jauh sebagai display ruang tersebut adalah muncul kebanggaan dan nilai simbolik dari pemiliknya. Namun dibalik pemujaan terhadap komoditas tersebut tampak absennya proses dibalik produksi berbagai furniture diantaranya kesenjangan sosial, tempat-tempat kumuh dan alienasi pekerja yang terlepas dari karyanya sebagai manusia (subjek).

Di bidang produksi dan konsumsi ruang di Indonesia, penetrasi dan pengembangan hubungan komoditas telah diselaraskan dengan ritme investasi. Pada tingkat baik pusat dan daerah, negara memfasilitasi kompetitif dari sudut pandang modal untuk berfungsinya kegiatan ekonomi (Castells, 1978:18). Demokratisasi media dan kebijakan negara berperan dalam proses akumulasi dan perannya dalam legitimasi. Namun, interpretasi mengenai aspek dari intervensi negara melalui kebijakan sangatlah kompleks, dan menjadi kekuatan yang turut mendukung adanya mekanisme pasar. Dititik ini terlihat bahwa media memainkan bentuk komodifikasinya terhadap ruang hunian yang kemudian difetiskan oleh khalayak sebagai suatu "kebutuhan palsu"

\section{Simpulan}

Pada bab ini penulis ingin meringkas hasil pembahasan dibagian sebelumnya mengenai konsep ruang dan komodifikasi yang dilakukan oleh media. Konsep pemikiran mengenai ruang sangatlah luas dan kompleks. Ruang dapat dipahami sebagai hasil dari konstruksi sosial, yang cair, dan tidak tetap. Bukan sebagai entitas yang alamiah, dan bebas dari aspek politik mapun osio-kultural. Media pada gilirannya mengambil peran dalam mengkomodifikasikan ruang hunian dari nilai kebutuhan manusia kedalam akumulasi kapital yakni mekanisme pasar. Hegemoni media dengan segala sumber daya yang dimilikinya memilih kontenkonten yang dianggap dapat menarik minat penontonnya, seperti yang dilakukan oleh program televisi d'SIGN NET. Media secara aktif mengkomodifikasikan ruang hunian urban dengan mengacu pada konsep dan tema, klasik, minimalis, maupun kontemporer kelas menengah atas atau elite. Tata ruang, posisi, bentuk furniture maupun warna membentuk estetika ruang hunian yang ideal. Di dalamnya juga 
terdapat kategorisasi ruang representasi di antaranya sebagai ruang tamu, ruang tidur, dapur, ruang anak, kamar mandi dan sebagainya. Lebih jauh, tayang ini merepresentasikan ruang sebagai objek fetish kepada khalayak, yang pada akhirnya bertujuan meningkatkan rating, maupun iklan dan menjadi bagian dari arus kapitalisme global.

\section{Referensi}

Arya, N., Cangara, H., \& Unde, A. A. (2016). Komodifikasi Kemiskinan dalam Televisi Indonesia. KAREBA: Jurnal Ilmu Komunikasi, 2(2), 175186.

Arifin, K. A. (2017). Perumahan Muslim dan Politik Ruang di Yogyakarta. Jurnal Pemikiran Sosiologi, 4(1), 42-56.

Barthes, Roland. 1973. Mythologies. Trans. by Annette Lavers. London: Paladin Books.

Beebe, K., Davis, A., \& Gleadle, K. (2012). Introduction: Space, Place and Gendered Identities: feminist history and the spatial turn. Women's History Review, 21(4), 523532. doi:10.1080/09612025.2012.658 172

Bouzida, F. (2014, September). The semiology analysis in media studies: Roland Barthes Approach. In International conference on social sciences and humanities, Istanbul (Vol. 8, No. 10).

Budiman, K. (2011). Semiotika Visual Konsep, Isu, dan Problem Ikonisitas. Yogyakarta: Jalasutra. 1-210.

Castells, M. (1978). City, Class, and Power. New York: St.

Christy, M., Alfatih, A., \& Wulantari, R. A. (2018). Komodifikasi Privasi di Media Massa: Studi pada Program Rumpi No Secret Trans TV 16 September (Doctoral dissertation, Sriwijaya University).

Foster, J. B., Napoletano, B. M., Clark, B., \& Urquijo, P. S. (2020). Henri
Lefebvre's Marxian ecological critique: recovering a foundational contribution to environmental sociology. Environmental Sociology, 6(1), 31-41.

Harvey, D. (2018). The limits to capital. Verso books.

Harvey, D. (1985). The Urbanization of Capital.

Hereyah, Y. (2012). Komodifikasi Budaya Lokal dalam Iklan: Analisis Semiotik pada Iklan Kuku Bima Energi Versi Tari Sajojo. In: Prosiding Seminar Nasional Menggagas Pencitraan Berbasis Kearifan Lokal. Purwokerto: Ilmu Komunikasi FISIP Universitas Jenderal Soedirman.

Herman, E. S., \& Chomsky, N. (1988). Manufacturing consent: A propaganda model. Manufacturing Consent.

Lefebvre, H. 1991. The production of space, Oxford: Blackwell.

McChesney, R. W. (1997). Corporate media and the threat to democracy (Vol. 1). Seven Stories Press.

Mendieta, E. (2008). The production of urban space in the age of transnational mega-urbes. City, 12(2), $\quad 148$ 153. doi:10.1080/1360481080225932 0

Merrifield, A. (1993) Place and space: A Lefebvrian reconciliation, Transactions of the Institute of British Geographers, 18(4), pp. 516-531.

Mosco, Vincent. (2009). The Political Economy of Communication 2 Edition. London: SAGE Publications Ltd. 1-268.

Murdock, G., Golding, P., \& Schlesinger, P. (1986). Communicating Politics: Mass Communications and the Political Process. Holmes \& Meier.

Myllylahti, M. (2017). What content is worth locking behind a paywall? Digital news commodification in leading Australasian financial newspapers. Digital Journalism, 5(4), 460-471. 
Schmid, C. (2008). Henri Lefebvre's theory of the production of space: Towards a three-dimensional dialectic. In Space, difference, everyday life (pp. 41-59). Routledge.

Shields, R. 1999. Lefebvre, love and struggle: spatial dialectics, London: Routledge.

Swastika, A. (2003). Komodifikasi Perempuan: Tapak Ekonomi Neoliberal. Jurnal Ilmu Sosial dan Politik, 7(2003).

Syafuddin, K., \& Andreas, R. (2018). Komodifikasi Nasionalisme Dalam
Iklan Sirup. Proceeding of The URECOL, 245-258.

Tracy, J. F. (2004). Between Discourse and Being The Commodification of Pharmaceuticals in Late Capitalism. The Communication Review, 7(1), 15-34.

Vera, N. (2015). Semiotika dalam Riset Komunikasi. Bogor: Ghalia Indonesia. 1-140.

Wasko, J. (2014). The study of the political economy of the media in the twentyfirst century. International Journal of Media \& Cultural Politics, 10(3), 259-271 